\title{
An Empirical Study of Female E-shopper's Satisfaction with Cosmetic Products in China
}

\author{
Yaxin $\mathrm{Ma}^{1} \&$ Shaohua Yang ${ }^{2}$ \\ ${ }^{1}$ Ph.D. Student, Finance Section, School of Management, Universiti Sains Malaysia, Penang, Malaysia \\ ${ }^{2}$ Ph.D. Student, Marketing Section, School of Management, Universiti Sains Malaysia, Penang, Malaysia \\ Correspondence: Yaxin Ma, Ph.D. Student, Finance Section, School of Management, Universiti Sains Malaysia, \\ Penang, Malaysia. E-mail: sunnyxin1220@163.com
}

Received: December 22, 2017

Accepted: January 22, 2018

Online Published: February 25, 2018

doi:10.5539/ijbm.v13n3p211

URL: https://doi.org/10.5539/ijbm.v13n3p211

\begin{abstract}
This study investigated the factors affecting female e-shopper's satisfaction with cosmetic products. Particularly it focuses on the online purchasing of cosmetics by female e-shoppers in five northwestern provinces in China. Previous literature claimed that price, quality and delivery speed of cosmetics have a profound impact on customer's online shopping satisfaction. Through comparison with physical stores' performance, price differences between online and offline, quality of products and delivery time help us understand the changes in e-shopper buying behavior. To bridge a gap in the current literature, we attempted to investigate which factor is most important to female e-shopper's satisfaction when they purchase cosmetic products online in China. We adopted a quantitative method in study. Factors analysis and reliability testing was conducted via SPSS. Our analysis indicated that price consciousness is the most influential factor in female e-shopper's satisfaction. Based on our findings and insights in this study, it suggested that if the online sellers can further adjust the price of cosmetic products or have regular online promotions, it will attract more consumers. In addition, online stores and suppliers should reach an agreement on small profits with quick turnover, thus achieving the dual interests of buyers and sellers. Several policy implications of female e-shopper's satisfaction with cosmetic products are discussed as well. Through our research, this study further provided conceptual basis for the study of Chinese consumers' online buying behavior.
\end{abstract}

Keywords: consumer behavior, female e-shopper's satisfaction, cosmetic products

\section{Introduction}

With the significant growth of e-commerce in China, more young people are adopting e-banking such as e-payment to purchase products. Online commerce is a key factor that can contribute to local economic growth. It is estimated that in China, e-commerce was worth $\$ 540$ billion by 2015 , and by 2020 will be worth more than that combined in the U.S., the UK, Japan, Germany and France (Kunz, 2013). Hence, research on the use of online shopping in different classification of industries is needed. Its purpose is to contribute to the development of e-commerce and economy. Particularly, the cosmetics industry is the most promising investment and the most dynamic consumer goods industry. In China, nearly $80 \%$ of the cosmetics market is occupied by foreign brands (사사 \& 이건희 2013). Obviously, the market shares of cosmetic industries will increase dramatically in e-commerce market.

With substantial increase in cosmetics' industry, various cosmetic brands have appeared on the online shopping list of Chinese consumers, especially overseas products (Wu, Cai, \& Liu, 2011). For the online shopping of cosmetic products, customers have more intention to purchase international brands of cosmetic products rather than local brands. Most consumers of online cosmetics shopping are young people between the ages of 20-39. More than $80 \%$ of customers purchased cosmetic products online (China Beauty Industry Insights, 2017). This fully indicated that the market potential for online cosmetics purchase is enormous, and Lynx, Taobao, and Jingdong are the three main online purchasing platforms. Although the online shopping becomes mature and provides convenience to customers, Liu and Hwang (2016) claimed that sometimes customers are not capable to meet their satisfaction after purchasing online cosmetic products. Due to the differences between online shopping and physical shopping, buyers are not able to try on cosmetic products. It is unknown whether the quality of products, delivery and price consciousness will influence customers' satisfaction. Therefore, this study 
mainly focuses on e-shopper's satisfaction with cosmetic products. Then it attempted to discover how to attract customers and get them onto the shopping platform, which is the embodiment of the competitive advantages of e-commerce providers (Dearnaley, 2013).

Among academic literature, the subject of customer satisfaction is important to commercial industries and this topic is worthy of continuous research. From the perspective of educational marketing, the degree of customers' satisfaction can influence the development of sustainable marketing strategy of its organisation (Yang \& Akhtaruzzaman, 2017; Yang \& Akhtaruzzaman, 2017). Additionally, numerous scholars have adopted customers' satisfaction as theoretical and empirical frameworks across various disciplines and contexts such as banking industries, hospitality industries and education industries (e.g., Ming \& Ing, 2005; Roger, 1996; Janna \& Chandra, 2016; Singh \& Dewan, 2009; Sim, Mak \& Jones, 2006; Yang, Chen \& Shen, 2017). By adopting quantitative methods, many scholars investigated factors that influence customers' satisfaction with online products purchasing and the results indicates that website design, quality of products, quality of service will affect the customers' satisfaction while they purchase products via website. (San Lim, Heng, Ng, \& Cheah, 2016; Casalo, Flavian, \& Guinalíu, 2008; Hansen \& Jensen, 2009). Though scholars above provided empirical evidence on the subject of online customers' satisfaction, this subject still has room for exploration, available literature also demonstrated that the demographic factors affect the level of customers' satisfaction while they purchase products online especially for the category of cosmetic products. China's cosmetics market is growing rapidly. Female e-shoppers' demand for cosmetic products is still a huge market in China. For instance, Omar, Bathgate, and Nwankwo (2011) stressed that improving Chinese female e-shopper's satisfaction is the key to expanding the market and profitability. Female consumers are the main purchasing force in online shopping. Passyn, Diriker and Settle (2011) studied that women have shown great enthusiasm in shopping. The main reason is that cosmetic products online are cheaper, and platforms online provides a less stressful shopping environment for consumers (Nam, 2014). Online Shopping is liquidity and more convenient, which makes women can shop anytime and anywhere (Sambargi \& Gopal, 2016). Satisfaction is a state of mind, which indicates consumers like this product after their payment. Female e-shopper's satisfaction differs between purchasing products and expecting the quality of products. For example, Hackstetter (2013) argued that if the reaction of female shoppers is ignored by one organisation, and finally consumers complain about it, which will lead to high levels of negative emotions and reduce female e-shopper's satisfaction levels. This will greatly affect the organisational reputation and the growth of sales. However, despite these studies on female satisfaction with purchasing cosmetic products online, there are very limited specific studies employing quantitative survey on level of female e-shopper's satisfaction. This failing leaves a crucial knowledge gap which e-commerce providers are concerned about. Further, little research that has investigated the level of customers' satisfaction with online shopping has focused on female in China. This is considered as the gap and the current study attempts to fill the gap in literature. Therefore, the main objective of this study is to investigate factors that influence female e-shopper's satisfaction in China by providing empirical evidence.

\section{Hypothesis Development}

Many consumers like to buy cosmetics online, and the main reason is cheap (Jeong, 2016). In particular, cosmetics prices with promotions online are lower than usual, greatly boosting the satisfaction of female e-shoppers, which was argued by Kuo, Huand and Yang (2013). The powerful promotional events like Alibaba Shopping Festival in China every year attracted hundreds of millions of costumers (Kim, Zhang, \& Zhang, 2016), which fully reflects the temptation of price. Thus, the hypothesis one is proposed below:

H1: Price consciousness influences e-shopper's satisfaction with cosmetic products in China.

Makadon et al. (2010) suggested that typically, cost and quality affect the value of the quality of the product, which are also the major factors of the success of e-commerce. In an era of online shopping, Chinese consumers like Hong Kong cosmetics very much (Naughton, 2012) because Hong Kong cosmetics are not only tax-free, but also have good quality reputation (Lin \& Chen, 2013). With the popularity of online shopping, customers are more willing to purchase Hong Kong cosmetics online because of good quality as mentioned by Popescu, Soceanu and Dobrinas (2014). Therefore, the hypothesis two is proposed below:

H2: Quality influences e-shopper's satisfaction with cosmetic products in China.

Delivery service for online shopping is the biggest bright spot and the "fundamental objective." Ha and Stoel (2012) found that it is a common goal of e-business and express delivery to establish a friendly business relationship with customers. Katawetawaraks and Wang (2011) mentioned that delivery is not only a key element of successful online business, but also one factor influencing female e-shopper's satisfaction since female customers are often anxious and looking forward to getting their products. Thus, the hypothesis three is proposed 
below:

H3: Delivery influences e-shopper's satisfaction with cosmetic products in China.

\section{Conceptual Framework}

The following conceptual framework was established in this study (Figure 1).

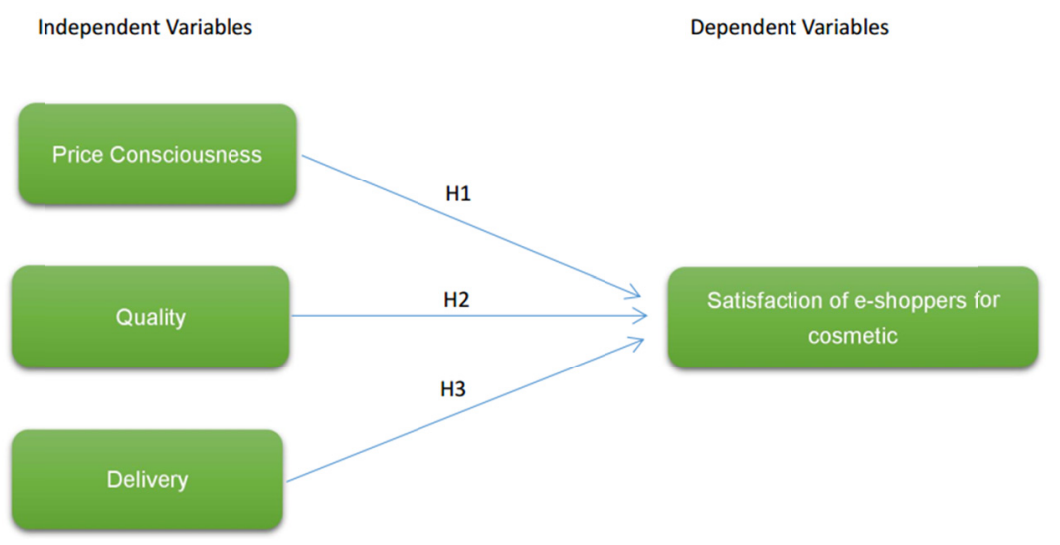

Figure 1. Conceptual framework

\section{Research Methodology}

A deductive approach was adopted in this study, and quantitative study is based on questionnaire, which is finished by people according to their own wishes in a structured manner. Those facts and statistics can bring reliable research results to researchers (Lipinski, Siemens \& Groome, 2013). It does not consider the probability sampling. The research mainly uses online data, focusing on potential respondents' questionnaires to collect data. In this study, the survey methodology was selected to find out female e-shoppers' satisfaction with cosmetic products and related factors in Chinese northwestern areas including Shanxi, Gansu, Qinghai, Ningxia and Xinjiang. Before conducting survey online, questionnaires were designed. The items in questionnaires have been re-adopted and revised following previous original studies.

In this study, measuring instruments are consumers' assessment tools, which measure the variables under investigation through surveys and data collection, especially through data analysis of questionnaires (Feyel, Üstünel \& Zakai, 2006). Among them, measurement methods are divided into preliminary tests and hypothetical tests. For this study, all of the data sources are from the questionnaire. The questionnaires were collected through network platforms, mainly through WeChat and E-mail. This approach is adapted to current trends, which is convenient and easy to supervise. Questionnaires take an anonymous form to ensure the security of consumers' personal information. Additionally, in this research, all questions in questionnaire are from section A to section $\mathrm{C}$. Items of section A are about e-shopper's satisfaction with cosmetic products; items of section B are three factors influencing e-shopper's satisfaction including price, quality and delivery; section $\mathrm{C}$ is about demographic information including gender, age, education background, occupation, income, race, location and years of experiences of online shopping. Section $\mathrm{A}$ to $\mathrm{C}$ uses a five-point Likert scale to measure degrees of satisfaction (O'Neill, 1993), the options range from 1 "strongly disagree" to 5 "strongly agree".

\subsection{Sample Size}

The sample of this study is based on the authors' connections in all walks of life. Due to the sparse population density in Northwest China, the authors expanded investigation to five provinces in Northwest China including Shansin, Gansu, Ningxia, Qinghai and Xinjiang. According to statistics, the total population of these five provinces has reached 90.90 million (Li \& Batten, 2011). Moreover, according to Krejcie and Morgan (1970), there is more than one million people in the region. To maintain the effectiveness and quality of the study, the sample size is 384 and questionnaires were distributed to $512(384 / 0.75=512) .300$ participants were required in this study in order to provide valid answers. Questionnaires were distributed in five provinces in Northwest China without any particular restrictions. Totally 286 questionnaires were completed by participants. However, due to the gender requirement, all participants in this questionnaire are women. 
Table 1 . Validity analysis and reliability test

\begin{tabular}{|c|c|c|c|c|c|}
\hline Items & Component & Loading & Alpha & $K M O$ & Sig. \\
\hline Satisfaction & S1 & .712 & .849 & .821 & .000 \\
\hline $\mathrm{S} 2$ & .727 & & & & \\
\hline S3 & .852 & & & & \\
\hline S4 & .823 & & & & \\
\hline S5 & .845 & & & & \\
\hline Price Consciousness & $\mathrm{P} 1$ & .747 & .778 & .762 & .000 \\
\hline $\mathrm{P} 2$ & .762 & & & & \\
\hline $\mathrm{P} 3$ & .662 & & & & \\
\hline P4 & .686 & & & & \\
\hline P5 & .797 & & & & \\
\hline Quality & Q1 & .561 & .694 & .650 & .000 \\
\hline Q2 & .755 & & & & \\
\hline Q3 & .605 & & & & \\
\hline Q4 & .689 & & & & \\
\hline Q5 & .757 & & & & \\
\hline \multirow[t]{5}{*}{ Delivery } & DE1 & .728 & .783 & .813 & .000 \\
\hline & DE2 & .805 & & & \\
\hline & DE3 & .581 & & & \\
\hline & DE4 & .743 & & & \\
\hline & DE5 & .802 & & & \\
\hline
\end{tabular}

The data in Table 1 are the whole data from 286 responders including factors like loading, KMO, and alpha values. All of data are in the range of 0.7-0.95, which means the data comply with the rule of Cronbach's Alpha (OKABE, 1986). In addition, KMO returns values are between 0-1. According to Staver (1972), Sig value is usually set below 5\%. Similarly, all data of sig are below 0.05 in this table. Thus, the 286 completed questionnaires can be accepted and it can be appropriate for further analysis.

\section{Findings and Discussion}

Table 2. Respondents' demographic profile $(\mathrm{N}=286)$

\begin{tabular}{llll}
\hline Variables & Category & Frequency & Valid Percentage \\
\hline Age & $18-24$ & 34 & $11.9 \%$ \\
& $25-34$ & 156 & $54.5 \%$ \\
Education Level & $35-44$ & 88 & $30.8 \%$ \\
& Above 45 & 8 & $2.8 \%$ \\
& High school & 37 & $12.9 \%$ \\
Diploma & 58 & $20.3 \%$ \\
Occupation & Bachelor's degree & 127 & $44.4 \%$ \\
& Master's degree & 47 & $16.4 \%$ \\
& Doctoral degree & 17 & $5.9 \%$ \\
& Student & 20 & $7.0 \%$ \\
& Employed & 102 & $35.7 \%$ \\
& Self- employed & 95 & $33.2 \%$ \\
& Housewife & 69 & $24.1 \%$ \\
& Others & 0 & $0 \%$ \\
\hline
\end{tabular}

The profile of the respondents in this study was demonstrated in Table 2 above. Out of 286 respondents. 11.8 percent of the respondents were grouped between 18 to 24 years old, followed by 30.8 percent of respondents aged 30 to 44 years old. The highest percentage respondents (54.5\%) were grouped between 35 to 44 years old. However, only $2.8 \%$ of respondents are above 45 years old. All respondents in the study were Chinese. Table 2 also indicated that the majority of the respondents $(44.4 \%)$ had got a bachelor's degree. The second higher percentage of respondents $(20.3 \%)$ hold diploma qualification. Only 5.9 percent of respondent had Doctoral 
degree. Moreover, Table 2 also demonstrated that 35.7 percent of respondents were employed, and 33.9 percent of respondents were self- employed.

Table 3. Result of regression

\begin{tabular}{cllllllll}
\hline Model & $\beta$ & Std. & Error & Beta & $t$ & Sig. & Tolerance & VIF \\
\hline \multirow{2}{*}{1} & IV Price & .417 & .066 & .380 & 6.299 & .000 & .456 & 2.195 \\
& IV Quality & .193 & .070 & .179 & 2.774 & .001 & .399 & 2.504 \\
& IV Delivery & .273 & .059 & .264 & 4.615 & .000 & .506 & 1.997 \\
\hline
\end{tabular}

\section{Dependent Variable: DV}

H1: Price influences e-shopper's satisfaction with cosmetic products in China.

From Table 3, the p-value of price in the regression test is less than .05. Therefore, it can be concluded that there is a significant relationship between female e-shoppers' perceived usefulness and satisfaction $(\beta=0.417$, $\mathrm{p}$-value $<0.05$ ). The survey results showed that the price consciousness of female consumers is 0.471 . This figure reflects consumer's high price consciousness, which again fully shows that price affects consumers' satisfaction to a large extent and the price is the most important factor influencing e-shopper's satisfaction. In line with previous studies (e.g., Jeong, 2016; Kuo, Huand, \& Yang 2013), the result of this study is similar. Online cosmetic sellers should implement price strategies which can influence female e-shopper's satisfaction with their cosmetic products. Female buyers prefer to look at cosmetic products with low prices online. Therefore, the hypothesis one is accepted.

H2: Quality influences e-shopper's satisfaction with cosmetic products in China.

The result of Table 3 showed that the p-value of quality in the regression test is less than .05 . Therefore, it can be concluded that there is a significant relationship between consumers' perceived usefulness and female e-shopper's satisfaction $(\beta=0.193$, $\mathrm{p}$-value $<0.05)$. The results indicated that one unit increase in perceived usefulness can increase 0.193 unit of female e-shopper's satisfaction level. Based on this analysis, the result revealed that high quality of products can affect the level of female e -shopper's satisfaction. Surprisingly, this result is also similar to previous research findings (e.g., Naughton, 2012 Lin \& Chen, 2013; Dobrinas 2014) which indicated that maintaining the quality of products is essential. If the quality of product is not standard sufficient, the level of e-shopper's satisfaction decreased. Consequently, combined with previous studies, results of this survey can support hypothesis two. Therefore, hypothesis two is accepted.

H3: Delivery influences e-shopper's satisfaction with cosmetic products in China.

From Table 3, we can see that the p-value of delivery in the regression test is less than .05. Therefore, it also reflects that there is a significant relationship between female e-shoppers' perceived usefulness and female e-shopper's satisfaction $(\beta=0.273$, p-value $<0.05)$. Simultaneously, the results also indicated that one unit increase in perceived usefulness can increase 0.273 unit of female e-shopper's satisfaction level. Hence, the survey of this study indicated that speeding up the delivery of products can influence the level of female e-shopper's satisfaction These results are also compatible with previous studies, with literature suggesting that express delivery online can establish further relationship with female e-shoppers (Katawetawaraks \& Wang 2011; Ha \& Stoel, 2012). Therefore, hypothesis three is accepted.

\section{Conclusion and Implication}

Based on our quantitative analysis of this study, the three hypotheses in this study were approved. Our result indicates that price consciousness, quality and delivery have an impact on females' satisfaction while they purchase cosmetic products online in China. In addition, this study also showed that women are the major customer groups in the cosmetics industry in China. The satisfaction of such consumers has a direct impact on the development of the Chinese cosmetics industry. The three hypotheses in this study directly affect consumers' satisfaction. Therefore, when female purchase cosmetic products online, Chinese e-commerce providers can improve female satisfaction through adjusting the price of products, speeding up the delivery and enhancing the quality of products. The level of female satisfaction increases when e-commerce providers establish a good reputation and attract more customers to achieve sustainable competitive advantages in Chinese online market.

Through data analysis, the three hypothetical arguments in this research are confirmed. Consumer satisfaction is closely related to the quality, price and delivery of cosmetic. 
Price consciousness: The results showed that price consciousness is the most important factor affecting consumers' satisfaction. Chinese female e-shoppers pay extra attention to the price of cosmetic products. Based on the findings of this study, it suggested that e-shoppers can find it more appealing to shop online if sellers online can further lower prices or have regular promotions. Online stores and suppliers should reach an agreement on carrying out small profits with quick turnover in order to achieve the dual interests of buyers and sellers.

Quality: For cosmetic quality, it can be concluded that its $\beta$ is 0.193 . Quality as another hypothetical problem also affects consumers' satisfaction. Compared with product prices, consumers seem to be able to accept the quality of online products. In any case, quality is also a measurement of consumers' satisfaction. There were also some differences between consumers' expectation about the product and the real feeling when they receive their package. This might also affect the customers' satisfaction. Therefore, it is recommended that online sellers should mark the quality of substandard goods for processing, thus improving the recognition of commodity representation.

In addition, it should be noted that the e-commerce requirements of the cosmetics evaluation system must be in graphic forms to ensure the uploaded information of products which is reliable and trustworthy. Subsequently, e-commerce providers are required to collect attached customers' feedbacks to improve the quality of products. At the same time, e-commerce should fully implement the rule of "l Fake, 10 Compensate".

Delivery: Product delivery service is an important part in the whole process of online shopping. Through the findings of this study, we obtained the delivery of $\beta$ value is 0.273 . It indicated that delivery increases by one unit can increase consumers' satisfaction by 0.273 units, which means that delivery is also one of the very important factors that can affect e-shopper's satisfaction. Delivery is most concerned with the delivery time, which means the entire consumption time from ordering online to receiving the product. The shorter the delivery time is, the higher the consumer's satisfaction. One suggestion is that sellers should improve the efficiency of delivery of goods and shorten the delivery time of goods. So, in the delivery process, sellers should reduce or cover the postage, thus improving delivery services, which will further improve customers' satisfaction.

This study has a range of contributions. Firstly, it provided online shopkeepers with insights to understand the female customers' satisfaction. Findings of this study were also helpful for female consumers to make decisions on online cosmetic product purchasing. From shopkeepers' perspective, they also can develop online promotion strategy based on female purchasing behaviours. Secondly, this study confirmed the purchasing behaviour of contemporary consumers and provided sample basis for future research on consumer behaviour. In addition, with substantial development of Chinese cosmetics industry, the successful transition from traditional purchasing to online purchasing also illustrates the full acceptance of online shopping by contemporary Chinese consumers. Finally, there was still a lack of academic literature of satisfaction with consumer's purchasing cosmetic products online (e.g., San Lim, Heng, Ng, \& Cheah, 2016; Casalo, Flavian, \& Guinalíu, 2008; Hansen \& Møller Jensen, 2009; San, Omar, \& Thurasamy, 2015). Consequently, this study also contributed to enlarging the body of literature on online consumers' satisfaction particularly in context of female customers in China.

\section{Limitations}

In this study, there were several limitations. First, all e-shoppers who participated in the questionnaire were mainly in Northwest China, which cannot fully represent consumption in China as a whole. Therefore, there were some geographical restrictions in this research. Second, there must be other factors that influence e-shopper's satisfaction with cosmetic products in China. Further research may focus on other factors and this could expand knowledge on e-shopper's satisfaction with cosmetic products. Third, in relation to methodology, a larger sample size could have been carried out to get more precise idea and achieve more reliable outcome of e-shopper's satisfaction. Further studies with a bigger sample size and including more participants would add to the generalizability of the findings.

\section{References}

Casaló, L. V., Flavián, C., \& Guinalíu, M. (2008). The role of satisfaction and website usability in developing customer loyalty and positive word-of-mouth in the e-banking services. International Journal of Bank Marketing, 26(6), 399-417. https://doi.org/10.1108/02652320810902433

China Beauty Industry Insights. (2017). Need-to-know news and analysis from the world's most dynamic beauty market. http://blog.chinabeautyexpo.com/my-blog/2017/02/inside-tmall-global-whats-behind-chinas-cross-border-b eauty-e-commerce-boom.html 
Dearnaley, P. (2013). Competitive advantage in the new contrived social care marketplace: How did we get here. Housing, Care and Support, 16(2), 76-84. https://doi.org/10.1108/hcs-03-2013-0002

Feyel, D., Üstünel, A., \& Zakai, M. (2006). The realization of positive random variables via absolutely continuous transformations of measure on wiener space. Probability Surveys, 3, 170-205. https://doi.org/10.1214/154957806000000069

Guo, J., \& Jaafar, N.I. (2011). A study on consumers' attitude towards online shopping in China. International Journal of Business and Social Science, 2(22). Retrieved from http://www.ijbssnet.com/journals/Vol_2_No_22_December_2011/15.pdf

Ha, S., \& Stoel, L. (2012). Online apparel retailing: Roles of e-shopping quality and experiential e-shopping motives. Journal of Service Management, 23(2), 197-215. https://doi.org/10.1108/09564231211226114

Hackstetter, T. (2013). China-the rising dragon in e-commerce: What foreign companies should be aware of when entering the Chinese online shopping market. (Unpublished bachelor thesis). Karelia University of Applied Sciences, Finland.

Hansen, T., \& Møller Jensen, J. (2009). Shopping orientation and online clothing purchases: the role of gender and purchase situation. European Journal of Marketing, 43(9/10), 1154-1170. https://doi.org/10.1108/03090560910976410

Jana, A., \& Chandra, B. (2016). Mediating role of customer satisfaction in the mid-market hotels: An empirical analysis. Indian Journal of Science and Technology, 9(1), 1-16. https://doi.org/10.17485/ijst/2016/v9i1/81973

Jeong, G. (2016). Experiences of Chinese consumers with Korean cosmetics brands: How do these relate to emotional consumption value. Korea International Trade Research Institute, 12(3), 137-164. https://doi.org/10.16980/jitc.12.3.201606.137

Jia, L., \& Choon-Sup, H. (2016). Chinese consumers' satisfaction with on-line purchasing agent services of Korean fashion products according to their selection criteria and information source. Journal of Distribution Science, 14(11), 117-128. https://doi.org/10.15722/jds.14.11.201611.117

Katawetawaraks, C., \& Wang, C. (2011). Online shopper behavior: Influences of online shopping decision. Asian Journal of Business Research, 1(2). https://doi.org/10.14707/ajbr.110012

Kim, S., Zhang, X., \& Zhang, B. (2016). Self-mocking crisis strategy on social media: Focusing on Alibaba chairman jack ma in china. Public Relations Review, 42(5), 903-912. https://doi.org/10.1016/j.pubrev.2016.10.004

Krejcie, R., \& Morgan, D. (1970). Determining sample size for research activities. Educational and Psychological Measurement, 30(3), 607-610. https://doi.org/10.1177/001316447003000308

Kunz, D. (2013). Gesellschaft für internationale zusammenarbeit, state administration for industry and commerce of the people's republic of china, china society of administration for industry and commerce (eds): e-commerce in china and germany-a sino-german comparative analysis. China-EU Law Journal, 1(3-4), 135-139. https://doi.org/10.1007/s12689-012-0017-x

Kuo, Y. F., Hu, T. L., \& Yang, S. C. (2013). Effects of inertia and satisfaction in female online shoppers on repeat-purchase intention: The moderating roles of word-of-mouth and alternative attraction. Managing Service Quality: An International Journal, 23(3), 168-187. https://doi.org/10.1108/09604521311312219

Li, J., \& Batten, D. (2011). Early Cretaceous palynofloral provinces in China: Western Additions Island Arc, 20(1), 35-42. https://doi.org/10.1111/j.1440-1738.2010.00715.x

Lin, W.T., \& Chen, C.Y. (2013). Shopping satisfaction at airport duty-free stores: A cross-cultural comparison. Journal of Hospitality Marketing \& Management, 22(1), 47-66. https://doi.org/10.1080/19368623.2012.680242

Lipinski, M. O., Siemens, D. R., \& Groome, P. A. (2013). Variations in prostate biopsy practice: A quantitative questionnaire-based study. Canadian Urological Association Journal, 7(11-12), E732. https://doi.org/10.5489/cuaj.372

Makadon, H., Bharucha, F., Gavin, M., Oliveira, J., \& Wietecha, M. (2010). Value management: optimizing quality, service, and cost. Journal for Healthcare Quality, 32(1), 29-34. https://doi.org/10.1111/j.1945-1474.2009.00061.x 
Ming, C. L., \& Ing, S. H. (2005). Relationships among service quality, customer satisfaction and profitability in the taiwanese banking industry. International Journal of Management, 22(4), 635-648. Retrieved from https://search.proquest.com/docview/233229927?accountid=14782

Nam, M. W. (2014). The influence of shopping orientation and sales promotion of cosmetic products on retail store selection behavior between male and female consumers. Journal of Digital Design, 14(3), 375-390. https://doi.org/10.17280/jdd.2014.14.3.038

Naughton, B. (Ed.). (2012). The China circle: Economics and technology in the PRC, Taiwan, and Hong Kong. Brookings Institution Press.

Okabe, Y. (1986). KMO-Langevin equation and fluctuation-dissipation theorem (I). Hokkaido Mathematical Journal, 15(2), 163-216. https://doi.org/10.14492/hokmj/1381518224

Omar, M., Bathgate, I., \& Nwankwo, S. (2011). Internet marketing and customer satisfaction in emerging markets: the case of Chinese online shoppers. Competitiveness Review, 21(2), 224-237. https://doi.org/10.1108/10595421111117489

O'Neill, P. (1993). Special section--Section spéciale: Issues in university education--Quelques questions à propos de l'enseignement universitaire. Canadian Psychology, 34(2), 164-165. https://doi.org/10.1037/h0084695

Passyn, K. A., Diriker, M., \& Settle, R. B. (2011). Images of online versus store shopping: Have the attitudes of men and women, young and old really changed. Journal of Business \& Economics Research, 9(1), 99. https://doi.org/10.19030/jber.v9i1.946

Popescu, V., Soceanu, A., \& Dobrinas, S. (2014). The quality control of some dermo-cosmetic products. Analele Universitatii" Ovidius" Constanta-Seria Chimie, 25(2), 85-90. https://doi.org/10.2478/auoc-2014-0016

Roger, H. (1996). The relationships of customer satisfaction, customer loyalty, and profitability: An empirical study. International Journal of Service Industry Management, 7(4), 27-42. https://doi.org/10.1108/09564239610129931

Sambargi, S., \& Gopal, R. (2016). Predicting online buying using shopping orientation - a study on online grocery shopping among women. PES Business Review, 11(1), 35. https://doi.org/10.21842/pes/2016/v11/i1/108930

San Lim, Y., Heng, P. C., Ng, T. H., \& Cheah, C. S. (2016). Customers' online website satisfaction in online apparel purchase: A study of Generation Y in Malaysia. Asia Pacific Management Review, 21(2), 74-78. https://doi.org/10.1016/j.apmrv.2015.10.002

San, L. Y., Omar, A., \& Thurasamy, R. (2015). Online purchase: a study of generation Y in Malaysia. International Journal of Business and Management, 10(6), 298. https://doi.org/10.5539/ijbm.v10n6p298

Sim, J., Mak, B., \& Jones, D. (2006). A model of customer satisfaction and retention for hotels. Journal of Quality Assurance in Hospitality \& Tourism, 7(3), 1-23. http://dx.doi.org/10.1300/j162v07n03_01

Singh, U., \& Dewan, J. (2009). Hotel management. New Delhi: APH Pub. Corp., in association with Indian Institute of Management.

Staver, A. (1972). Precipitation is usually below normal. Weatherwise, 25(5), 234-239. https://doi.org/10.1080/00431672.1972.9931609

Wu, L., Cai, Y., \& Liu, D. (2011). Online shopping among Chinese consumers: An exploratory investigation of demographics and value orientation. International Journal of Consumer Studies, 35(4), 458-469. https://doi.org/10.1111/j.1470-6431.2010.00982.x

Yang, S., \& Akhtaruzzaman, M. (2017). Effective marketing techniques in recruiting international students: evidence from a tertiary institute in New Zealand. Journal of Engineering and Applied Sciences, 12(2), 336-352. Retrieved from http://docsdrive.com/pdfs/medwelljournals/jeasci/2017/336-352.pdf

Yang, S., \& Akhtaruzzaman, M. (2017). Should polytechnics rely solely on international agents to recruit international students? A Case Study in New Zealand. International Journal of Marketing Studies, 9(6), 14-23. https://doi.org/10.5539/ijms.v9n6p14

Yang, S., Chen, X., \& Shen, X. (2017). An exploratory study of customer satisfaction with international student recruitment agencies: a case study in New Zealand. International Journal of Business and Management, 12(11), 130-140. https://doi.org/10.5539/ijbm.v12n11p130

사사 \& 이건희. (2013). Chinese market entry strategy of Korean cosmetics -focused on brand positioning. 
China and Sinology, 20, 67-92. https://doi.org/ 10.17935/chinan.2013.20.67

\section{Copyrights}

Copyright for this article is retained by the author(s), with first publication rights granted to the journal.

This is an open-access article distributed under the terms and conditions of the Creative Commons Attribution license (http://creativecommons.org/licenses/by/4.0/). 